\title{
Picoplanktonic algae in the northern Baltic Sea: seasonal dynamics and flagellate grazing
}

\author{
Harri Kuosa
}

Tvärminne Zoological Station, SF-10900 Hanko, Finland

\begin{abstract}
The seasonal succession of picoplanktonic algae was followed from March to December 1986 at a station off Tvärminne, northern Baltic Sea. This area is characterized by strong seasonal changes in water temperature and stratification. Picoeukaryotes were abundant during the whole year $\left(10^{3}\right.$ to $\left.10^{4} \mathrm{ml}^{-1}\right)$, but picocyanobacteria thrived only during summer $\left(10^{5}\right.$ to $\left.10^{6} \mathrm{ml}^{-1}\right)$. The contrasting seasonal dynamics of these 2 groups led to the conclusion that growth of picocyanobacteria is more temperature dependent than that of the almost equally sized picoeukaryotes. However, the cyanobacterial dynamics could not be explained by temperature alone and light climatic changes may have contributed to the drastic decline of cyanobacterial numbers in the warm deep-mixed water column in the autumn. Estimates of flagellate grazing on picoplanktonic cyanobacteria were obtained by differential filtration experiments. These showed that flagellates could graze vigorously on picoalgae. Total flagellate grazing on picoalgae amounted to $15 \%$ of annual primary production, and was estimated to be 32 and $42 \%$ during summer and autumn, respectively. The microbial loop seems to be of major quantitative importance in the boreal northern Baltic Sea.
\end{abstract}

\section{INTRODUCTION}

The fate of pelagic primary production is of great interest in marine ecology. The absolute quantity of phytoplankton production varies, and with it the amount of energy available to consumers at different trophic levels. However, production in carbon units is not the only factor which governs the flow of carbon to the large grazers.

In recent studies of marine ecosystem much attention has been given to the microbial loop, a term introduced by Azam et al. (1983). A substantial part of the primary production may have to be transformed from dissolved to particulate form by bacteria, of which the most important grazer group is considered to be heterotrophic nanoflagellates (Fenchel 1982, Wikner \& Hagström 1988). Energy flow through the microbial loop decreases the overall efficiency of the carbon transfer to the top predators, compared to the simple grazing food chain (Ducklow et al. 1986), even if these micrograzers (nanoflagellates and other protozooplankton) are eventually consumed by higher trophic levels (Sherr et al. 1986, Sherr \& Sherr 1988). Of course, the same holds if a part of the primary production is grazed directly by micrograzers. Heterotrophic nanoflagellates are known to graze on picoplanktonic algae as well, and this will be one route of energy transfer from primary producers to the microbial loop (Johnson et al. 1982, Caron et al. 1985, Parslow et al. 1986, Hagström et al. 1988, Nagata 1988).

The Baltic Sea, a large brackish water basin, is characterized by strong seasonal changes; the northern Baltic is covered with ice for several months in winter, and usually has a clear temperature stratification during summer. The role of bacteria and heterotrophic nanoflagellates in the pelagic carbon cycle was assessed by Kuosa \& Kivi (1989). The present study concentrated on the seasonal succession of picoplanktonic algae, which are considered a potential food source for nanoflagellates. Flagellate grazing on picoalgae is also estimated experimentally. The objective of this study was to quantify the direct link from primary producers to nanoflagellates, and to estimate the role of nanoflagellates as herbivores in the pelagic ecosystem of the northern Baltic Sea.

\section{MATERIAL AND METHODS}

Investigation area. Sampling was done at a station off Tvärminne Långskär, Finland $\left(59^{\circ} 50^{\prime} \mathrm{N}, 23^{\circ} 10^{\prime} \mathrm{E}\right)$. The main physical and biological characteristics of the 
area were briefly described in Kuosa \& Kivi (1989), and in more detail in Niemi $(1973,1975)$ and Kuparinen et al. (1984). The station is situated in an oligotrophic open sea area at the entrance to the Gulf of Finland. Mean salinity is $6 \%$. After the break up of the ice in spring, inorganic nutrients mineralized during the winter are used by a heavy phytoplankton bloom. Sedimentation of large algae (diatoms and dinoflagellates) removes nutrients from the surface water layer, which causes low summer production in the thermally stratified water column. The thermocline is situated at about $10 \mathrm{~m}$. Occasionally during summer, upwelling bring new nutrients to the surface water. The thermocline detoriates in autumn, after which deep mixing occurs.

Seasonal succession. Sampling was carried out from March to December 1986, at $1 \mathrm{wk}$ intervals during winter and autumn and twice a week during spring and summer. A surface sample, representing the 0 to $5 \mathrm{~m}$ layer, was obtained by combining subsamples from depths of $0.5,1.5,2.5,3.5$ and $4.5 \mathrm{~m}$. Samples from $10 \mathrm{~m}$ and $20 \mathrm{~m}$ were obtained by combining 3 subsamples from each depth. Sampling was performed between 09:30 and 10:30 h. When the sea was ice-covered, samples were taken from 0,1 and $15 \mathrm{~m}$ only.

Autotrophic picoplankton was counted on formalinfixed (final conc. $2 \%$ ) samples within 6 h of the sampling. Five $\mathrm{ml}$ of the sample were filtered with $<10 \mathrm{kPa}$ vacuum onto an Irgalan black-stained 0.2 um poresized Nuclepore polycarbonate filter (Hobbie et al. 1977). The filter was mounted on paraffin oil and picoalgal cells were enumerated with a Leitz Dialux epifluorescence microscope fitted with a HBO-50 mercury lamp. A $100 \times$ oil immersion objective, a $3 \mathrm{~mm}$ BG 12 exciting filter, a built-in $2 \times \mathrm{KP} 490$ (= KP 500) interference filter and a K 510 suppression filter were used. At least 100 cells of both picoplanktonic cyanobacteria and picoeukaryotes were counted on the majority of samples. Cyanobacteria were identified by their orange and eukaryotes by their red autofluorescence under the blue excitation light. The number of eukaryotes is thus the abundance of $<2.0 \mu \mathrm{m}$ chloroplasts in the sample.

Chlorophyll a was determined with a Turner 111 fluorometer on duplicate $50 \mathrm{ml}$ samples, which were filtered onto a Whatman GF/F glass fibre filter, subjected to ultrasonic waves for $5 \mathrm{~min}$ and extracted in $96 \%$ ethanol at room temperature for $24 \mathrm{~h}$. Standard methods were used for the analysis of phosphate-phosphorus, nitrate-nitrogen and ammonium-nitrogen (Grasshoff 1976, Kororeff 1976).

Grazing experiments. Flagellate grazing on picoplanktonic cyanobacteria was studied with differential filtration experiments (Wright \& Coffin 1984). A sample was filtered through $5 \mathrm{um}$ and 1 um filters. No vacuum was needed for the $5 \mu \mathrm{m}$ filtration, but a gentle $(<2 \mathrm{kPa})$ vacuum was used for the $1 \mu \mathrm{m}$ filter. According to microscopy no ciliates were present in the $<5$ um fraction, and only a few flagellates could squeeze through the $1 \mu \mathrm{m}$ filter. In the first 7 experiments in 1988, duplicate $1 \mathrm{I}$ samples in glass bottles were incubated in situ at $1 \mathrm{~m}$ depth. In the 4 last experiments the bottles were darkened, but incubated at in situ temperature.

One subsample from each bottle was taken daily. It was fixed with glutaraldehyde (final conc. $1 \%$ ) and examined within $4 \mathrm{~h}$ of sampling. Heterotrophic nanoflagellates and picoplanktonic cyanobacteria were enumerated on $5 \mathrm{ml}$ proflavine-stained samples (Haas 1982), which were filtered with $<3 \mathrm{kPa}$ vacuum and otherwise processed as described above, except that black Nuclepore filters provided by the manufacturer were used. Flagellates were counted under blue excitation light (filter set I2/3), and cyanobacteria under green excitation light (filter set M2). At least 100 flagellates and 200 cyanobacteria were counted per sample, except for the flagellates in the $<1 \mu \mathrm{m}$ filtrate, in which usually only 10 to 20 flagellates could be found with acceptable effort.

Grazing was estimated to be the difference between the specific growth rates $(\mu$; based on $\ln )$ in the $1 \mu \mathrm{m}$ and $5 \mu \mathrm{m}$ filtrates (Frost 1972). Flagellate clearance rates were estimated by calculating the grazing loss $[\mu(1 \mu \mathrm{m})-\mu(5 \mu \mathrm{m})]$ and dividing it by the mean number of grazers (Frost 1972). The average grazer number between samplings was calculated by applying an exponential growth curve to flagellates (Heinbokel 1978). In the first experiment, the calculations were made for a period of $96 \mathrm{~h}$, because of the low water temperature and slow changes in prey abundance. In the other experiments, the grazing calculations were made for a period of $48 \mathrm{~h}$. Two days seems to be near the minimum time for filtration experiments in the study area, due to the relatively slow changes in prey abundances. However, the 6 experiments were continued for $96 \mathrm{~h}$ to obtain the growth rates of flagellates in the $<1 \mu \mathrm{m}$ filtrate. In many summer samples flagellates grew rapidly in the $<1 \mu \mathrm{m}$ filtrates, although the initial flagellate value was less than $1 \%$ of the total. However, no more than 200 flagellates $\mathrm{ml}^{-1}$ were found in the 'flagellate-free' fraction during the first $48 \mathrm{~h}$. This is about $10 \%$ of the usual summer abundance of flagellates. Due to contamination of the $<1 \mu \mathrm{m}$ fraction (which is unavoidable in our waters) the grazing estimates are likely to be underestimates

\section{RESULTS}

The seasonal dynamics of nitrate-nitrogen, temperature and chlorophyll $a$ in 1986 are given in Fig. 1. 


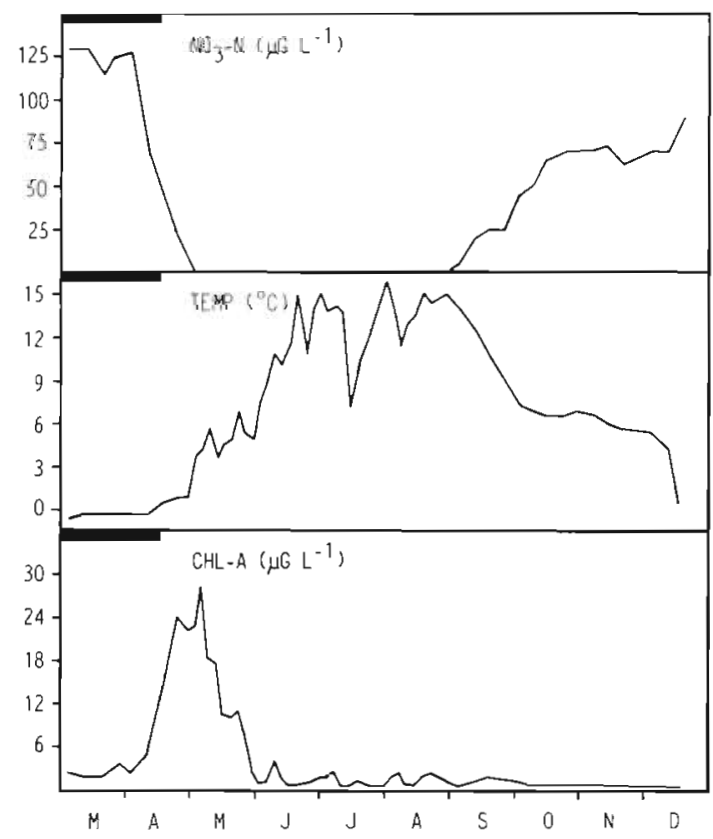

Fig. 1 Nitrate-nitrogen, temperature and chlorophyll a (surface values) at a station off Tvärminne, northern Baltic Sea, in 1986. Black bar denotes ice cover

Nitrate values crashed from the high winter value to near 0 level due to uptake by rapidly growing phytoplankton in April and May. The dynamics of the phosphate-phosphorus values were nearly identical to those of nitrate-nitrogen. The winter value of phosphatephosphorus was 20 to $23 \mu \mathrm{gl}^{-1}$, and the summer values about $1 \mu \mathrm{g} \mathrm{1^{-1 }}$. The only difference from the nitrate dynamics was 2 short ( $1 \mathrm{wk}$ ) phosphate maxima after upwellings in July and August. These upwellings can be seen as a decrease in the surface temperature in Fig. 1. The phosphate-phosphorus values rose to about 10 and $5 \mu \mathrm{g} \mathrm{l}^{-1}$, respectively. The surface chlorophyll values decreased rapidly after the exhaustion of inorganic nutrients and remained low through the rest of year (Fig. 1). The nitrate-nitrogen (and also phosphatephosphorus) values started to increase again in September after the thermocline deteriorated and mixing began to occur deeper in the water column. A short maximum of ammonium-nitrogen (up to $10 \mu \mathrm{gl}^{-1}$ ) was observed after the 2 upwellings in July and August. In September a short maximum of ammonium-nitrogen was observed, with values up to $38 \mu \mathrm{gl}^{-1}$, but during the rest of the year the values varied between 2 and $5 \mu \mathrm{g} \mathrm{l}^{-1}$.

The abundance of the eukaryotic picoplankton showed little clear-cut seasonal variation, but rather a zigzag type of fluctuation (Fig. 2). However, some general features are evident. First, the eukaryotic picoplankton was already abundant during the cold water

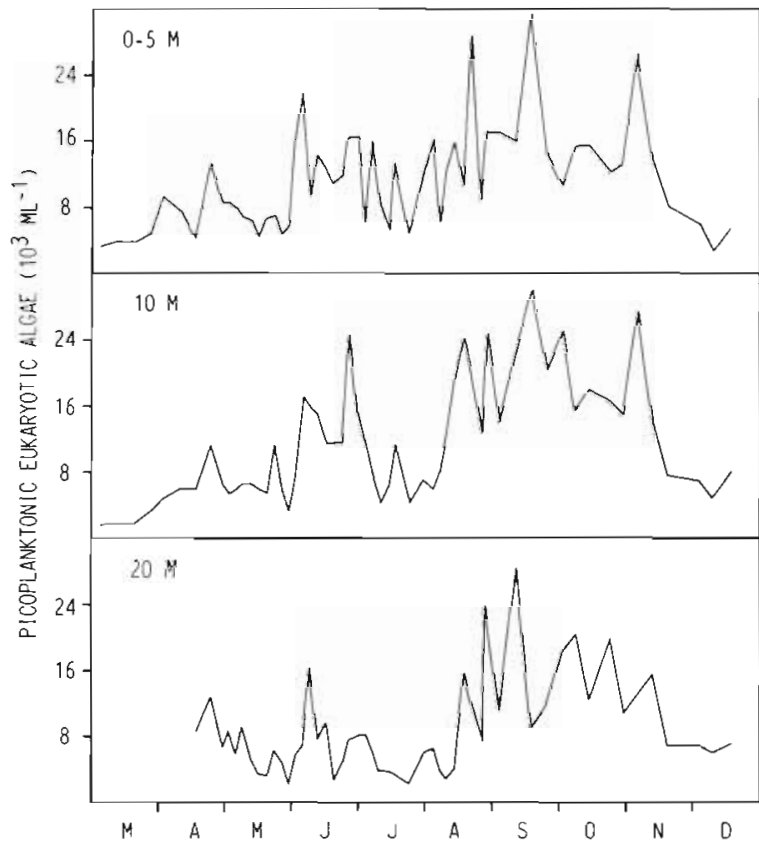

Fig. 2. Abundance of picoplanktonic eukaryotes (surface, 10 and $20 \mathrm{~m}$ values) off Tvärminne in 1986. During the period of ice cover, the surface value is the mean of the values for 0 and

$1 \mathrm{~m}$, and the $10 \mathrm{~m}$ value is in fact the value for $15 \mathrm{~m}$

period before the spring bloom. Second, the maximum occurred in autumn during deep mixing, when a large number of eukaryotic picoplankton was present in the whole water column down to at least $20 \mathrm{~m}$.

The abundance of cyanobacteria showed a much more pronounced pattern than that of eukaryotes (Fig. 3). A sharp increase in cell number coincided with 3 other phenomena: the crash of inorganic nutrients,

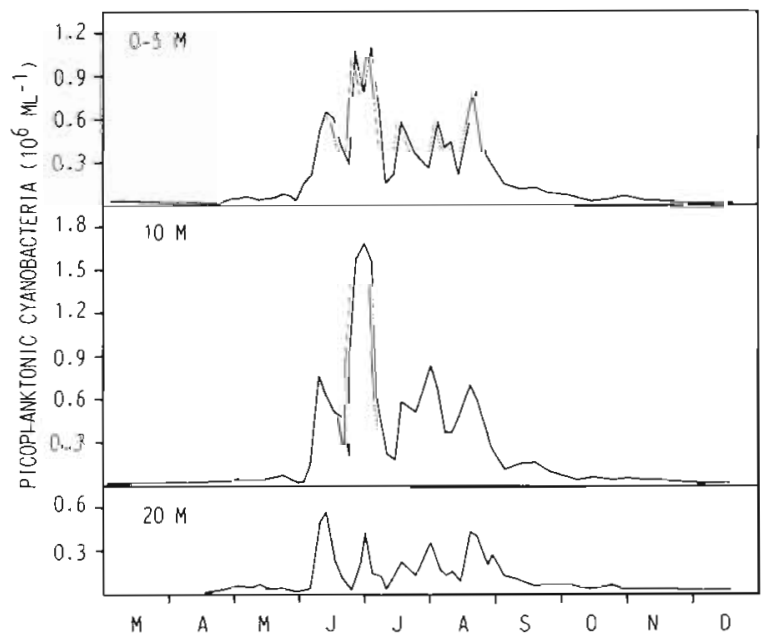

Fig. 3. Abundance of picoplanktonic cyanobacteria (surface, 10 and $20 \mathrm{~m}$ values) off Tvärminne in 1986. During the period of ice cover the surface value is the mean of the values for 0 and $1 \mathrm{~m}$, and the $10 \mathrm{~m}$ value is in fact the value for $15 \mathrm{~m}$ 
Table 1 Results of 11 grazing experiments in 1988. Starting date, water temperature $\left({ }^{\circ} \mathrm{C}\right)$, numbers of picoplanktonic cyanobacteria $\left(10^{3} \mathrm{ml}^{-1}\right)$ and heterotrophic nanoflagellates $\left(\mathrm{ml}^{-1}\right)$ in the $<5 \mu \mathrm{m}$ filtrate and clearance rate $\left(10^{-6} \mathrm{ml} \mathrm{flag}^{-1}\right.$ $\mathrm{h}^{-1}$ ). The number of cyanobacteria ingested (cells flag. ${ }^{-1} \mathrm{~d}^{-1}$ ) and the total $<5$ um flagellate grazing on the cyanobacterial population $\left(\% \mathrm{~d}^{-1}\right)$ are estimated from the clearance rates and the number of prey in the initial communty

\begin{tabular}{|lrrrrrr|}
\hline Expt & Temp. & Pico. & Flag. & Clear. & Grazed & $\%$ \\
\hline 24 Apr & 0.7 & 7 & 688 & 8.1 & 1.3 & 13 \\
13 May & 8.2 & 7 & 1067 & 3.8 & 0.6 & 8 \\
25 May & 10.4 & 33 & 2151 & 2.6 & 2.1 & 13 \\
7 Jun & 15.5 & 71 & 2469 & 2.5 & 4.3 & 15 \\
27 Jun & 21.2 & 392 & 1453 & 6.6 & 62.1 & 10 \\
4 Jul & 20.0 & 750 & 1937 & 11.4 & 205.2 & 53 \\
18 Jul & 23.3 & 517 & 969 & 7.6 & 94.3 & 18 \\
24 Jul & 21.7 & 213 & 2426 & 4.3 & 22.0 & 25 \\
29 Jul & 17.7 & 170 & 1322 & 7.2 & 29.4 & 23 \\
3 Aug & 13.4 & 155 & 3470 & 1.3 & 4.8 & 11 \\
8 Aug & 14.9 & 290 & 1700 & 0.4 & 2.8 & 2 \\
\hline
\end{tabular}

the temperature rise from near 0 to $10^{\circ} \mathrm{C}$ and finally, the rapid decline of the spring bloom. The mean summer abundances were $0.5 \times 10^{6} \mathrm{ml}^{-1}$, but the maximum number of cyanobacteria approached that of bacteria $\left(10^{6} \mathrm{ml}^{-1}\right)$. The decline of cyanobacterial numbers coincided with the deterioration of the thermocline in August, and the consequent deep mixing.

Not surprisingly, the abundances of both picoalgal groups showed little variation in their dynamics with depth. Cyanobacteria were not especially abundant at $20 \mathrm{~m}$, possibly due to a slow sedimentation rate. However, the abundances of picoplanktonic cyanobacteria and eukaryotes correlated poorly with each other. Eukaryotic algae showed very little tendency to follow

Table 2. Specific growth rates $(\mu)$ of heterotrophic nanoflagellates in the $<5 \mu \mathrm{m}$ fraction (maximum growth rate in the $<1$ $\mu \mathrm{m}$ fraction) and of picoplanktonic cyanobacteria and heterotrophic bacteria in the $<1 \mu \mathrm{m}$ fraction (all values $d^{-1}$ ). Dates denote start of experiment. nd: not determined

\begin{tabular}{|lccc|}
\hline Expt & $\mu_{\text {fleg }}$ & $\mu_{\text {cyamo }}{ }^{\circ}$ & $\mu_{\text {bact }}$ \\
\hline 24 Apr & $-0.15(0)$ & -0.07 & 0.04 \\
13 May & $0.27(0.75)$ & 0 & 0.14 \\
25 May & $0.11(0.44)$ & 0.16 & 0.14 \\
7 Jun & $0.35(1.14)$ & 0.53 & 0.21 \\
27 Jun & $0.70(1.38)$ & 0.32 & 0.12 \\
4 Jul & $0.56(1.44)$ & 0.47 & 0.08 \\
18 Jul & $0.64(1.98)$ & 0.30 & -0.09 \\
24 Jul & 0.57 nd & nd & 0.13 \\
29 Jul & 1.00 nd & 0.42 & 0.22 \\
3 Aug & 0.09 nd & nd & 0.17 \\
8 Aug & 0.03 nd & 0.02 & 0.23 \\
a Values from Kuosa $(1990)$ & & \\
\hline
\end{tabular}

the surface temperature, which seemed at least partly to control cyanobacterial growth.

Flagellate clearance rates varied from 0.4 to $11.4 \times$ $10^{-6} \mathrm{ml} \mathrm{flag.}^{-1} \mathrm{~h}^{-1}$. If the first early spring grazing experiment at near $0^{\circ} \mathrm{C}$ is excluded, the experiments conducted at higher temperatures indicated that flagellate activity is temperature dependent (Table 1). The clearance values at temperatures under $15^{\circ} \mathrm{C}$ were consistently lower than those at 18 to $23^{\circ} \mathrm{C}$. The number of cyanobacterial cells grazed per flagellate (calculated from the initial prey abundance) varied more than the clearance rate as a consequence of large variation in cyanobacterial abundance. A flagellate would eat a maximum of about 200 cyanobacteria $\mathrm{d}^{-1}$. i.e. about $8 \mathrm{~h}^{-1}$. The mortality (Table 1, \% grazed) caused by the flagellate population in the cyanobacterial population varied from 2 to $53 \% \mathrm{~d}^{-1}$ (mean $17 \%$ ). The mean growth rate of cyanobacteria was $0.24 \mathrm{~d}^{-1}$. The bacterial growth rates in the $<1 \mu \mathrm{m}$ fraction were low compared with the cyanobacterial or flagellate growth rates (Table 2). Flagellates showed very high growth rates during some summer experiments in the $<1 \mu \mathrm{m}$ fraction. The maximum $\left(1.98 \mathrm{~d}^{-1}\right)$ corresponds to a cell division time of about $8 \mathrm{~h}$.

\section{DISCUSSION}

The mean size of picoplanktonic cyanobacteria in the northern Baltic Sea is about $1 \mu \mathrm{m}$ (Kuosa 1988). The majority of cells were identified as belonging to the genus Synechococcus, to which most of the picoplanktonic cyanobacteria in the world's oceans have been referred. The cells are basically solitary, but in summer they form small groups (Kuosa 1988). Picoplanktonic eukaryotic algae most probably belong to a variety of classes. Their identification is possible only by electron microscopy. One problem in counting picoplanktonic eukaryotes arose due to the enumeration of chloroplasts only, which was done in order to avoid any masking by proflavine. There is a danger that cells with multiple chloroplasts could be counted as several picoalgae. However, this problem rarely existed in the samples. There are only 2 genera of flagellates which could have real importance as a source of error, and the position of chloroplasts with respect to each other in both Chrysochromulina (2 chloroplasts) and Pedinella ( 3 chloroplasts) is so characteristic that they are easily identified.

This seasonal study confirms the results of an earlier exercise, in which it was suggested that the abundance of picoplanktonic algae in the northern Baltic is comparable with that of the world's oceans (Kuosa 1988). In fact, cyanobacterial numbers as high as $10^{6} \mathrm{ml}^{-1}$ have only rarely been reported (from the Tropical Pacific; Li 
et al. 1983). The summer abundances found in 1986 were somewhat higher than the values in the southern Baltic Sea (Jochem 1988) and the coastal oceanic abundances, and they were 1 or 2 orders of magnitude higher than the oligotrophic or cold-water ocean values (Johnson \& Sieburth 1979, Waterbury et al. 1979, 1986, Smith et al. 1985, Glover et al. 1986, Iturriaga \& Marra 1988, Shapiro \& Haugen 1988). The number of eukaryotic picoplankters in the northern Baltic Sea was within the range of the values reported from the coastal stations of the North Atlantic, and in general an order of magnitude higher than the abundance at oligotrophic ocean stations (Murphy \& Haugen 1985).

Despite the minor difference in the sizes of prokaryotic and eukaryotic picoalgae, there seem to be profound differences in their seasonal dynamics. Eukaryotes were abundant almost throughout the year, whereas the abundance of picoplanktonic cyanobacteria showed a clear correlation with the surface water temperature. However, the decline during the period of deep mixing in August and September rules out control of cyanobacterial abundance by temperature alone.

In a study from the same area, cyanobacteria were found to be reluctant to grow at temperatures $<10^{\circ} \mathrm{C}$ (Kuosa 1990), which is in accordance with the dynamics in 1986. This fits the general scheme of Waterbury et al. (1986), who did not find Synechococcus cell numbers exceeding $10^{5} \mathrm{ml}^{-1}$ at temperatures below $4{ }^{\circ} \mathrm{C}$. El Hag \& Fogg (1986) and Jochem (1988) also report a positive correlation between cyanobacterial abundance and water temperature from the Menai Straits (Wales) and the southern Baltic Sea, respectively. Both Caron et al. (1985) and Weisse (1988) suggest a similar relationship in lakes. However, Shapiro \& Haugen (1988) report a possible cold-water race or species of Synechococcus from the North Atlantic. They found that Synechococcus clones from warm waters did not grow in temperatures of $<8$ to $10^{\circ} \mathrm{C}$. In view of this finding. I would suggest that the picoplanktonic Synechococcus inhabiting the northern Baltic Sea behaves more like a warm-water Synechococcus, and that there are no indications of a cold-water race.

As there was no decrease in the water temperature during the drop of Synechococcus, the reason for the decline of the cyanobacterial population in autumn is likely to be found in the changing characteristics of the water column. Either lower light intensity, which will prevail in a deep mixing environment, or increased water turbulence can inhibit cyanobacterial growth. Low light intensity alone may initiate a rapid decline of cyanobacteria, although we know that these are capable of light-saturated photosynthesis at very low irradiances (Li et al. 1983, Platt et al. 1983, Glover et al. 1985). However, Campbell \& Carpenter (1986a) found that Synechococcus grew better at surface light intensities than at $1 \%$ light level. The reason for the apparently low growth rates in the autumn may also be rapid changes in the light environment due to mixing, which sharply contrast to the situation in summer during stable stratification. Deep mixing and large detrital particles, which are always found in the water column during deep mixing, may also change the light quality experienced by the cells towards the more yellow-red area of the spectrum. Marine Synechococcus was not found to show chromatic adaptation (Waterbury et al. 1986), and the northern Baltic Sea populations may not utilize the modified light spectrum effectively.

Eukaryotes evidently gained some advantage from the mixing in autumn, as their number remained high for some months. Thus, in the northern Baltic Sea eukaryotes were not as dependent on water temperature and water stability as were cyanobacteria. The phytoplankton in general was not stimulated by the deep mixing in August, at least if judged by the chlorophyll values. However, the deep mixing most probably caused a shift in the phytoplankton species composition, and possibly also in the picoplanktonic eukaryotic community.

The nutrient supply had evidently little or nothing to do with the dynamics of picoalgae. Small algal cells are probably able to make efficient use of the small regenerated nutrient pool in summer. Direct evidence is still lacking that nutrients are not limiting, but the picoalgal dynamics in the northern Baltic Sea are clearly mainly controlled by other factors. In the southern Baltic Sea, Jochem (1989) also found the greatest contribution of picoalgae during the season of regenerated production in summer.

Flagellate clearance rates on cyanobacteria were in the range reported for flagellate grazing on bacteria (e.g. Kuuppo-Leinikki 1990 from the northern Baltic Sea). It is not surprising to find effective grazing on nearly bacterial sized algal cells. The importance of cyanobacterial grazing is further emphasized by the high number of cyanobacteria and other picoalgae.

Flagellate grazing was a relatively important source of cyanobacterial mortality in the summer experiments of 1988. Between 2 and $53 \%$ of the population was grazed in a day. However, the mean population grazing rate of about $20 \%$ during the summer was low compared with the specific growth rates (Table 2). The specific growth rates in summer varied from 0.02 to $0.53 \mathrm{~d}^{-1}$, averaging $0.32 \mathrm{~d}^{-1}$. Thus flagellate grazing mortality was lower than the average growth rate of cyanobacteria. This would imply the existence of other factors causing losses in the cyanobacterial population. It is easy to point to the effect of other protozoan grazers than flagellates, e.g. ciliates, on cyanobacterial 
dynamics. Landry et al. (1984) concluded that cyanobacterial growth in Kaneohe Bay, Hawaii, may exceed the mortality caused by flagellate grazing, which is also the conclusion indicated by the present material. In Lake Constance, Weisse (1988) found that protozoan grazers caused almost the total cyanobacterial mortality. Campbell \& Carpenter (1986b) found that protozoan grazing varied between stations. At an open ocean station it did not reach the cyanobacterial growth rates, but at a neritic station cyanobacterial growth and protozoan grazing were in balance.

Another possible cause of the loss of cyanobacteria is sedimentation via copepod faecal pellets, which apparently contain undigested cyanobacterial cells (Johnson et al. 1982, Caron et al. 1985, Iturriaga \& Mitchell 1986). However, these faecal pellets may be disrupted at the surface due to the activity of the copepods themselves (Lampitt et al. 1990), and, consequently, the sedimentation rate may be only moderate. The significance of sources of loss other than flagellate grazing should be studied in detail.

Both the average flagellate growth rates in the $<5 \mu \mathrm{m}$ fractions and the maximum growth rates in the $<1 \mu \mathrm{m}$ fractions showed a clear effect of temperature (Table 2) - a multispecies community response similar to that observed by Caron et al. (1986) for a single species. The highest growth rates were observed in the 'flagellate-free' $<1 \mu \mathrm{m}$ fraction after a couple of days, as the few flagellates which succeeded in squeezing through the filter could grow for some time with minimum competition for food. Flagellate growth in the $<5 \mu \mathrm{m}$ fraction could indicate heavy grazing pressure on flagellates during most of the year (Table 2). However, flagellate growth in the $<5 \mu \mathrm{m}$ filtrates cannot be strictly attributed only to cessation of the grazing impact. Competition for food may also be reduced in the filtrate, and filtering may change the quality of the food, e.g. by breaking up small colonies of cyanobacteria so that they are more easily utilized by flagellates. The growth rates indicate an ability of the flagellates to outgrow or at least keep in pace with their picoplanktonic food sources.

The estimates of carbon consumption by nanoflagellates are presented in Table 3 . The original flagellate numbers per $\mathrm{m}^{2}$ from Fig. 5 in Kuosa \& Kivi (1989) have been applied. The clearance rates from the 1988 experiments were used for the calculations of picoaigal consumption. As summer 1986 was cold (max. water temperature $15^{\circ} \mathrm{C}$ ) a clearance value from the lower end of the experimental range was used $\left(1.5 \times 10^{-6} \mathrm{ml} \mathrm{h}^{-1}\right)$ in order to obtain a conservative estimate of carbon consumption. Grazing on picoeukaryotes was also calculated, as Landry et al. (1984) found no clear difference in the flagellate grazing on cyanobacteria and a small Chlorella. The prey number per $\mathrm{m}^{2}$ was estimated as
Table 3. Carbon flow estimates at a station off Tvärminne, northern Baltic Sea. Primary production, flagellate grazing on cyanobacteria and eukaryotic picoplankton, grazing of algae by flagellates as \% of the total algal production and bacterial production per $\mathrm{m}^{2}$ (all values in carbon)

\begin{tabular}{|lrcrrr|}
\hline & $\begin{array}{r}\text { Prim. } \\
\text { prod. }\end{array}$ & Cyano. & Eukar. & $\%$ & $\begin{array}{c}\text { Bact. } \\
\text { prod. }\end{array}$ \\
\hline Winter & 3.2 & 0.1 & 0.1 & 6 & 0.5 \\
Spring & 47.8 & 0.7 & 0.5 & 3 & 5.6 \\
Summer & 22.6 & 4.4 & 2.8 & 32 & 5.1 \\
Autumn & 8.6 & 1.1 & 2.5 & 42 & 1.4 \\
Total & 82.2 & 6.3 & 5.9 & 15 & 12.6 \\
a Values from Kuosa \& Kivi(1990) & & & \\
\hline
\end{tabular}

the bacterial production in Kuosa \& Kivi (1989), i.e. the mean cell numbers at the surface and $10 \mathrm{~m}$ were used for the 0 to $15 \mathrm{~m}$ water layer and the $20 \mathrm{~m}$ value for the 15 to $40 \mathrm{~m}$ layer. The mean volumes of $0.38 \mu^{3}$ and 2.0 $\mu^{3}{ }^{3}$ were used for cyanobacteria and picoeukaryotes, respectively. A carbon content of $0.22 \mathrm{pg} \mathrm{C} \mathrm{mm}^{-3}$ was used for both groups, from Li (1986).

It is readily seen that seasonal differences exist in the basic routes of the carbon flow to flagellates. In spring, flagellates seem to be largely dependent on bacteria, whereas in summer carbon flow estimates show picoalgae as a major flagellate food source. The grazing on cyanobacteria may be overestimated because of their occasional tendency to form small colonies in summer This has been taken into account by assuming only half of the cells to be utilizable. The majority of these colonies will be broken or retained by the filter when screened for the grazing experiments. The direct link between the algal community and flagellates was estimated to account for little more than $30 \%$ of the primary production in summer This value is in accordance with the fractionated chlorophyll and carbon uptake measurements made in 1988 (Kuosa 1990), which showed the $<3 \mu \mathrm{m}$ fraction to contain a considerable part of both chlorophyll (35 to $55 \%$ ) and production ( 25 to $45 \%$ ) in summer Flagellates were mostly dependent on picoalgae in autumn, but due to the maximum of eukaryotic cells they, and not cyanobacteria, were the major component in the flagellate diet Unfortunately, we lack fractionated chlorophyll and primary production estimates for the autumn.

According to the carbon flow estimates for 1986 , about $15 \%$ of the annual primary production was used directly by flagellates. For rough calculations an estimate of $50 \%$ respiration may be applied for both bacteria and flagellates. Accordingly, $15 \%$ of algal production may be expected to be respired by bacteria, and $7 \%$ by direct flagellate grazing on picoalgae. An 
additional $8 \%$ is respired if flagellates graze the total bacterial production. Thus, annually about $30 \%$ of the carbon produced is lost at the very base of the food web. If sedimentation accounts for an additional $40 \%$ loss (Kuparinen et al. 1984), a relatively meagre share of the annual production remains for the larger zooplankters. These values are largely in accordance with the carbon flow estimates in Kuosa \& Kivi (1989), but are now based on direct assessment of flagellate grazing on algae.

In conclusion, during summer and autumn, an appreciable proportion of the pelagic carbon flow in the northern Baltic Sea is directed through the microbial loop. The food web model approaches that for the oligotrophic Mediterranean (Hagström et al. 1988), although it is never so extreme. In their experiment, Hagstrom et al. (1988) estimated that $86 \%$ of the algal production was respired by bacteria and protozoa. In our boreal waters, however, the seasonal variation is considerable. It ranges from the inactive generally icecovered winter stage via the spring bloom composed of large rapidly sinking algae and a moderate carbon flow through the microbial loop, to the subsequent warm season with a high contribution to the microbial loop.

Acknowledgements. This study was performed at Tvärminne Zoological Station as a contribution to the PELAG project. The work was funded by the Nottbeck Foundation.

\section{LITERATURE CITED}

Azam, F., Fenchel, T., Field, J. G., Meyer-Reil, L.-A., Thingstad, F. (1983). The ecological role of water-column microbes in the sea. Mar Ecol. Prog. Ser 10: 257-263

Campbell, L., Carpenter, E. J. (1986a). Diel patterns of cell division in marine Synechococcus spp. (Cyanobacteria): use of the frequency of dividing cells technique to measure growth rate. Mar Ecol. Prog. Ser 32: 139-148

Campbell, L., Carpenter, E. J. (1986b). Estimating the grazing pressure of heterotrophic nanoplankton on Synechococcus spp. using the sea water dilution and selective inhibitor techniques. Mar Ecol. Prog. Ser. 33: 121-129

Caron, D. A., Goldman, J. C., Dennett, M. R. (1986). Effect of temperature on growth, respiration and nutrient regeneration by an omnivorous microflagellate. Appl. environ. Microbiol. 52: 1340-1347

Caron, D. A., Pick, F. R., Lean, D. S. R. (1985). Chroococcoid cyanobacteria in Lake Ontario: vertical and seasonal distributions during 1982. J. Phycol. 21: 171-175

Ducklow, H. W., Purdie, D. A., Williams, P. LeB., Davies, J. M. (1986). Bacterioplankton: a sink for carbon in a coastal marine plankton community. Science 232: 865-867

El Hag, A. G. D., Fogg, G. E. (1986). The distribution of coccoid blue-green (Cyanobacteria) in the Menai Straits and the Irish Sea. Br Phycol. J. 21: 45-54

Fenchel, I (1982). Ecology of heterotrophic microflagellates. IV Quantitative occurrence and importance as bacterial consumers. Mar Ecol. Prog. Ser. 9: 35-42

Frost, B. W (1972). Effects of size and concentration of food particles on the feeding behaviour of the marine plank- tonic copepod Calanus pacificus. Limnol. Oceanogr 17 : 805-815

Glover, H. E., Phinney, D. A., Yentsch, C. S. (1985). Photosynthetic characteristics of picoplankton compared with those of larger phytoplankton populations in various water masses in the Gulf of Maine. Biol. Oceanogr. 3: 223-248

Glover, H. E., Campbell, L., Prezelin, B. B. (1986). Contribution of Synechococcus spp. to size-fractionated primary productivity in three water masses in the Northwest Atiantic Ocean. Mar Biol. 91: 193-203

Grasshoff, K. (1976). Determination of nitrate. In: Grasshoff, K. (ed.) Methods of seawater analysis. Verlag Chemie, Weinheim, p. $137-145$

Haas, L. W (1982). Improved epifluorescence microscopy for observing planktonic microorganisms. Annls Inst. océanogr., Paris 58 (Suppl.): 55-60

Hagström, A.. Azam, F., Andersson, A., Wikner, J., Rassoulzadegan, F. (1988). Microbial loop in an oligotrophic pelagic marine ecosystem: possible roles of cyanobacteria and nanoflagellates in the organic fluxes. Mar Ecol. Prog. Ser. 49: 171-178

Heinbokel, J. F. (1978). Studies on the functional role of tintinnids in the Southern California Bight. I. Grazing and growth rates in laboratory cultures. Mar Biol. 47: 177-189

Hobbie, J. E., Daley, R. J., Jasper, S. (1977). Use of Nuclepore filters for counting bacteria by fluorescence microscopy. Appl. environ. Microbiol. 33: 1225-1228

Iturriaga, R., Marra, J. (1988). Temporal and spatial variability of chroococcoid cyanobacteria Synechococcus specific growth rates and their contribution to primary production in the Sargasso Sea. Mar Ecol. Prog. Ser 44:175-181

Iturriaga, R., Mitchell, B. G. (1986). Chroococcoid cyanobacteria: a significant component in the food web dynamics of the open ocean. Mar Ecol. Prog. Ser. 28: 291-297

Jochem, F. (1988). On the distribution and significance of picocyanobacteria in a boreal inshore area (Kiel Bight, Western Baltic). J. Plankton Res. 10: 1009-1022

Jochem, F. (1989). Distribution and importance of autotrophic ultraplankton in a boreal inshore area (Kiel Bight, Western Baltic). Mar. Ecol. Prog. Ser 53: 153-168

Johnson, P. W., Sieburth, J. McN. (1979). Chroococcoid cyanobacteria in the sea: a ubiquitous and diverse phototrophic biomass. Limnol. Oceanogr 24: 928-935

Johnson, P. W., Xu, H-S., Sieburth, J. McN. (1982). The utilization of chroococcoid cyanobacteria by marine protozooplankters but not by calanoid copepods. Annls Inst. océanogr., Paris 58 (Suppl.): 297-308

Koroleff, F. (1976). Determination of phosphorus and determination of ammonia. In: Grasshoff, K. (ed.) Methods of seawater analysis. Verlag Chemie, Weinheim, p. 117-133

Kuosa, H. (1988). Occurrence of autotrophic picoplankton along an open sea - inner archipelago gradient in the Gulf of Finland, Baltic Sea. Ophelia 28: 85-93

Kuosa, H. (1990). Picoplanktonic cyanobacteria in the northern Baltic Sea: role in the phytoplankton community. In: Barnes, M., Gibson, R. N. (eds.) Proc. 24th Europ. Mar Biol. Symp., Aberdeen Univ. Press, Aberdeen, p. 11-17

Kuosa, H., Kivi, K. (1989). Bacteria and heterotrophic flagellates in the pelagic carbon cycle in the northern Baltic Sea. Mar Ecol. Prog. Ser. 53: 93-100

Kuparinen, J., Leppänen, J.-M., Sarvala, J., Sundberg, A., Virtanen, A. (1984). Production and utilization of organic matter in a Baltic ecosystem off Tvärminne, southwest coast of Finland. Rapp. P.-v. Réun. Cons. int. Explor. Mer 183: 180-192

Kuuppo-Leinikki, P. (1990). Protozoan grazing on planktonic bacteria and its impact on bacterial population. Mar Ecol. Prog. Ser. 63: 227-238 
Lampitt, R. S., Noji, T., von Bodungen, B. (1990). What happens to zooplankton faecal pellets? Implications for material flux. Mar Biol. 104: 15-23

Landry, M. R. Haas, L. W., Fagerness, V L. (1984). Dynamics of microbial plankton communities: experiments in Kaneohe Bay, Hawaii. Mar Ecol. Prog. Ser 16: 127-133

Li, W K. W. (1986). Experimental approaches to field meas. urements; methods and interpretation. In: Platt, T., Li, W K. W (eds.) Photosynthetic picoplankton. Can. Bull. Fish. Aquat. Sci. 214, p. 251-286

Li, W K. W., Subba-Rao, D. V., Harrison, W. G., Smith, J. C.. Cullen, J. J., Irwin, B., Platt, T (1983). Autotrophic picoplankton in the tropical ocean. Science 219: 292-295

Murphy, L. S., Haugen, E. M. (1985). The distribution and abundance of phototrophic ultraplankton in the North Atlantic. Limnol. Oceanogr. 30:47-58

Nagata, T (1988). The microflagellate-picoplankton food linkage in the water column of Lake Biwa. Limnol. Oceanogr 33: $504-517$

Niemi, $\AA$. (1973). Ecology of phytoplankton in the Tvärminne area, SW coast of Finland. I. Dynamics of hydrography, nutrients, chlorophyll-a and phytoplankton. Acta bot. fenn. 100: $1-68$

Niemi, $\AA$. (1975). Ecology of phytoplankton in the Tvärminne area, SW coast of Finland. II. Primary production and environmental conditions in the archipelago zone and the sea zone. Acta bot. fenn. 105: 1-73

Parslow, J. S., Doucette, G. J., Taylor, F. J. R., Harrison, P. J (1986). Feeding by the zooflagellate $P$ seudobodo sp. on the picoplanktonic prasinomonad Micromonas pusilla. Mar. Ecol. Prog. Ser. 29: 237-246

Platt, T., Subba-Rao, D. V., Irwin, B. (1983). Photosynthesis of

This article was submitted to the editor picoplankton in the oligotrophic ocean. Nature, Lond. 301: 702-704

Shapiro, L. P., Haugen, E. M. (1988). Seasonal distribution and temperature tolerance of Synechococcus in Boothbay Harbor, Maine. Estuar. coast. Shelf Sci. 26: 517-525

Sherr, E. B., Sherr, B. F. (1988). Role of microbes in pelagic food webs: a revised concept. Limnol. Oceanogr. 33: 1225-1227

Sherr, E. B., Sherr, B. F., Paffenhöfer, G.-A. (1986). Phagotrophic protozoa as food for metazoans: a 'missing' trophic link in marine pelagic food webs? Mar microbiol. Food Webs 1: 61-80

Smith, J. C., Platt, T., Li, W. K. W., Horne, E. P. W., Harrison, W. G., Subba Rao, D. V., Irwin, B. D. (1985). Arctic marine photoautotrophic picoplankton. Mar. Ecol. Prog. Ser. 20: $207-220$

Waterbury, J. B., Watson, S. W., Guillard, R. R. L., Brand, L. E. (1979). Widespread occurrence of a unicellular, marine, planktonic cyanobacterium. Nature, Lond. 277: 293-294

Waterbury, J. B., Watson, S. W., Valois, F. W., Franks, D. G. (1986). Biological and ecological characterization of the marine unicellular cyanobacterium Synechococcus. In: Platt, T., Li, W K. W. (eds.) Photosynthetic picoplankton. Can. Bull. Fish. Aquat. Sci. 214, p. 71-120

Weisse, T. (1988). Dynamics of autotrophic picoplankton in Lake Constance. J. Plankton Res. 10: 1179-1188

Wikner, J., Hagström, А. (1988). Evidence for a tightly coupled nanoplanktonic predator-prey link regulating the bacterivores in the marine environment. Mar. Ecol. Prog. Ser. 50: $137-145$

Wright, R. T., Coffin, R. B. (1984). Measuring microzooplankton grazing on planktonic marine bacteria by its impact on bacterial production. Microb. Ecol. 10: 137-149

Manuscript first received: July 30, 1990

Revised version accepted: March 28, 1991 